Portland State University

PDXScholar

$11-1-2018$

\title{
Key Supplier Involvement in IT-enabled Operations: When Does it Lead to Improved Performance?
}

Fred Miao

Portland State University, fred.miao@pdx.edu

Guangping Wang

Penn State University

Pornsit Jiraporn

Penn State University

Follow this and additional works at: https://pdxscholar.library.pdx.edu/busadmin_fac

Part of the Business Commons

Let us know how access to this document benefits you.

\section{Citation Details}

Miao, F., Wang, G., \& Jiraporn, P. (2018). Key supplier involvement in IT-enabled operations: When does it lead to improved performance? Industrial Marketing Management, 75, 134-145. https://doi.org/10.1016/ j.indmarman.2018.05.002

This Post-Print is brought to you for free and open access. It has been accepted for inclusion in Business Faculty Publications and Presentations by an authorized administrator of PDXScholar. Please contact us if we can make this document more accessible: pdxscholar@pdx.edu. 


\title{
Key Supplier Involvement in IT-Enabled Operations: When Does It Lead to Improved Performance?
}

\begin{abstract}
As firms continue to invest in IT resources and collaborate with key suppliers, many fail to benefit from these activities. Drawing on resource orchestration theory and the relational view of interfirm competitive advantage, we examine the contingent relationships among IT resources, key supplier involvement, and the focal firm's performance. Using a multi-informants dataset from the manufacturing sector in China, we find that supplier involvement mediates the positive effect of IT resources on the focal firm's performance only when there is a high level of mutual trust and when competitive intensity is low in the focal firm's environment. In a highly competitive environment, however, mutual trust dampens the positive effect of supplier involvement on the focal firm's performance, which reveals the "hidden costs" of interfirm trust. In contrast, the direct positive effect of IT resources on the focal firm's performance is amplified by mutual trust when competitive intensity is high, suggesting that the focal firm will fare better without supplier involvement under these conditions. Therefore, key supplier involvement in the focal firm's IT-enabled operations does not always lead to improved performance and its effect on performance is contingent on relational and environmental variables.
\end{abstract}

Key words: IT resources; supplier involvement; firm performance; mutual trust; competitive intensity 


\section{Key Supplier Involvement in IT-Enabled Operations: When Does It Lead to Improved Performance?}

\section{Introduction}

As the business environment becomes more competitive, firms increasingly look to external resources such as key suppliers to build and sustain their competitive advantage (Song $\&$ Benedetto, 2008; Walter, 2003; Yeniyurt et al., 2014). Supplier involvement entails a close collaborative relationship in which the supplier directly participates in the customer's product design and implementation processes such that the supplier's expertise can be effectively integrated (Fossas-Olalla et al., 2015; Yeniyurt et al., 2014). As Ireland et al. (2002) suggest, this type of interfirm alliance is becoming the new paradigm of competition rather than the stand-alone competition between individual firms. While supplier involvement can enhance the focal firm's competitive advantage by developing collective value-creating resources that the focal firm cannot create independently (Dyer and Singh, 1998; Ireland et al., 2002), some researchers have cautioned against indiscriminant employment of supplier involvement as a generic strategy in that many such collaborative efforts failed to deliver intended benefits (Smets et al., 2013). In fact, sometimes supplier involvement can even dampen performance (Das et al., 2006), which may be caused by hampered organizational learning or loss of objectivity especially in strong supplier-customer relationships (Jean et al., 2014; Villena et al., 2011).

A related issue in buyer-seller relationships is the role of information technology (IT). While the literature generally posits that employment of IT resources facilitates the development of firm-level competitive advantage, research has failed to establish a direct, definitive link between IT resources and firm performance (Brynjolfsson \& Hitt, 1998; Lucas, 1999; Santhanam 
\& Hartono, 2003), which suggests that the effects of IT resources on firm performance are more likely indirect and context-specific. It has been suggested that the performance outcomes of IT resources are a function of the combination of other resources that are complementary with the focal resource (Chadwick et al., 2015). Although it is relatively easy to imitate or acquire similar IT resources by competing firms, knowledge reconfiguration, creation, and application resulting from key supplier involvement are much more socially complex, causally ambiguous, and tacit in nature, which becomes very difficult for competitors to imitate (Wernerfelt, 1984). In other words, IT resources can provide a platform that enables the focal firm to dynamically deploy and reconfigure its resources by effectively learning and integrating the supplier's knowledge and expertise (Fawcett et al., 2011; Wu, Wu, \& Si, 2016). From the perspective of resource orchestration theory (Sirmon et al., 2011), IT resources provide an efficient means through which the focal firm's own knowledge and expertise can be augmented and combined with the key supplier's skills and technologies by the focal firm's deliberate strategic choices (e.g., supplier involvement). Although scholars have highlighted the importance of interorganizational deployment of IT resources (Ragatz et al., 1997; Saeed et al., 2011), it is surprising that very few studies have explicitly considered the role of supplier involvement in the IT-enabled environment, given the role of IT in connecting the buyer and supplier firms in decision-making and operational processes. Therefore, the extent to which the focal firm's IT resources can be an effective tool in integrating the key supplier's resources in the focal firm's own operations, thereby rendering the focal firm a competitive advantage, remains to be seen. It seems reasonable that the power of interfirm resource orchestration can only be harnessed through wellcoordinated interfirm collaborations made efficient by IT technologies. 
The above review of the IT and supplier involvement literature gives rise to two important research questions. First, because IT resources will more likely become a true source of competitive advantage when they are used to acquire, accumulate, and bundle complementary resources from an exchange partner via interfirm collaboration (Dyer and Singh, 1998; Hitt et al., 2011; Ireland et al., 2002), a logical research question is: To what extent does supplier involvement mediate the positive effect of IT resources on the focal firm's performance? Second, interfirm collaboration such as supplier involvement involves resource sharing, tacit knowledge exchange, and interorganizational learning, all of which may expose both exchange partners to risks such as partner opportunism and learning races resulting from divergent motivations and goals (Ireland et al., 2002). Therefore, a critical boundary condition of the effective supplier involvement is interfirm trust (i.e., mutual trust), which may be the most effective means of safeguard against partner opportunism (Dyer and Singh, 1998) and can facilitate interfirm cooperation (Morgan and Hunt, 1994). However, research has also uncovered negative, albeit unexpected effects of mutual trust on interfirm collaboration where innovation or market responsiveness may suffer (Anderson and Jap, 2005; Fang et al., 2008). That is, interfirm trust may have its "hidden costs", although conditions under which such dark side effects of mutual trust may outweigh its benefits remain unclear. Because the contingencies of resource-related strategic choices (e.g., supplier involvement) are "poorly understood and form a critical future research agenda" (Sirmon and Hitt, 2009, p.1375), our second research question responds to this call and askes: Under what conditions will supplier involvement lead to improved performance of the focal firm's IT-enabled operations?

Drawing on resource orchestration theory (Chadwick et al., 2015; Hitt et al., 2011; Sirmon et al., 2011) and the relational view of interorganizational competitive advantage (Dyer 
and Singh, 1998), this study proposes a moderated mediation model of IT-enabled supplier involvement (Figure 1). Empirical results using a multi-informants dataset collected from the manufacturing sector in China provide compelling support for the research framework. In particular, we find that supplier involvement partially mediates the positive effect of IT resources on the focal firm's performance, which highlights the value of supplier involvement in the ITenabled resource orchestration process. However, supplier involvement is not a "silver bullet" as results indicate that mutual trust and competitive intensity in the focal firm's environment are critical boundary conditions. When competitive intensity is low, mutual trust amplifies the positive mediation effect of supplier involvement; in contrast, when competitive intensity is high, the "hidden costs" of mutual trust may outweigh its benefits, thereby significantly compromising the value of supplier involvement. In fact, when both competitive intensity and mutual trust are high, the focal firm will actually fare much better without supplier involvement, possibly because the focal firm benefits from supplier cooperation while not falling victim to routine rigidity and cognitive lock-in typically embedded in closely integrated interfirm operations (Fang et al., 2008).

We organize the remainder of this paper as follows. After a review of relevant literature, we formulate research hypotheses grounded in resource orchestration theory and the relational view of interorganizational competitive advantage. We then describe our research methods and report empirical results. We conclude the paper with a discussion of implications to theory and practice, limitations of the current study, and future research directions.

-- Figure 1 about here --

\section{Literature Review}

\subsection{Information technology (IT) resources}


Information technology (IT) is a critical organizational resource in cultivating strategically important interfirm relationships (Lee \& Scott, 2015). While there is no unanimously agreed-upon definition, IT resources typically include two interrelated elements: (1) IT infrastructure such as computer hardware, software, and communication systems and (2) technical and managerial IT skills (Bharadwaj, 2000; Davis \& Golicic, 2010; Ryssel et al., 2004). That is, IT resources include both tangible (e.g., computer equipment) and intangible (e.g., skills) dimensions in its operational definition.

Although it is commonly held that IT resources can improve firm performance, scholars have struggled to establish conclusive evidence linking IT resources to superior financial performance (Bharadwaj, 2000; Dong et al., 2009; Hitt \& Brynjolfsson, 1996). For example, while Bharadwaj (2000) reported that firms with high IT-enabled capabilities tend to have significantly higher profit ratios, Hitt \& Brynjolfsson (1996) discovered a negative relationship between IT investment and profitability, yet Ryssel et al. (2004) found that IT deployment had no significant effects on value creation in business relationships. Empirically, many firms have made substantial investments in IT resources without deriving anticipated benefits (Bharadwaj, 2000; Vanpoucke et al., 2014). These inconsistent findings are unsettling as they directly question the value of IT (Dong et al., 2009; Hitt \& Brynjolfsson, 1996).

Because IT infrastructure can be acquired and duplicated fairly easily by competitors, IT investments per se cannot become a source of sustainable competitive advantage (Bharadwaj, 2000; Davis \& Golicic, 2010). According to the resource orchestration theory, the outcomes of a resource deployment are determined by how the focal resource is effectively combined with other relevant resources in its deployment (Chadwick et al., 2015; Sirmon et al., 2011). That is, resources of a focal firm should be structured, bundled, and leveraged with complementary 
resources, which usually come from a collaborative partner, to maximize value creation and form a competitive advantage (Dyer and Singh, 1998; Sirmon et al., 2011). IT-enabled integration with a strategically important partner (e.g., key supplier) can turn their complementary knowledge and skills into valuable, causally ambiguous, and hard-to-imitate interfirm resources and routines. Consistent with this view, researchers have advocated investigating how IT resources can be deployed to integrate with other resources in an interorganizational setting, which ultimately affects firm performance (Jean et al., 2010; Lee \& Scott, 2015; Ryssel et al., 2004).

\subsection{Supplier involvement}

Firms are increasingly searching for external sources for innovation, value creation, and competitive advantage (Walter, 2003; Yeniyurt et al., 2014). Among those external sources, key suppliers are recognized as important partners for reducing new product development time, improving product quality and service, obtaining access to new technologies and markets, and lowering operations costs (Menguc et al., 2014; Yeniyurt et al., 2014).

Because companies must successfully integrate suppliers' technologies and skills in order to reconfigure their own resources to meet their strategic and operational needs, firms typically involve their key suppliers in their product development and operations processes (Das et al., 2006; Vanpoucke et al., 2014). Supplier involvement refers to the extent to which a supplier directly participates in the focal firm's new product development and operations processes (Jean et al., 2014). While some research indicated that supplier involvement can enhance the focal firm's innovation, operational and financial performance (Afuah, 2000; Carr \& Pearson, 2002; Frohlich \& Westbrook, 2001; Menguc et al., 2014), other studies either found no significant effects or even reported negative influences of supplier involvement (Rodrigues et al., 2004; 
Swink et al., 2007; Vereecke \& Muylle, 2006). As such, considerable ambiguity remains with respect to the effect of supplier involvement on the focal firm's performance outcomes (Das et al., 2006; Primo \& Amundson, 2002). Another outstanding issue regarding supplier involvement as a resource-related strategic choice is whether supplier involvement is a universally viable strategy or there are contingencies under which it may become ineffective and even counterproductive (Sirmon and Hitt, 2009), especially when IT resources of the focal firm are employed in integrating and routinizing the key supplier's involvement in the operations process. While some researchers have indicated the importance of IT in supplier integration practices (Ragatz et al., 1997), few studies have explicitly linked IT resources to supplier involvement in affecting firm performance.

\subsection{Interfirm trust}

According to the relational view of interorganizational competitive advantage (Dyer and Singh, 1998; Ireland et al., 2002), although interfirm linkages (e.g., IT-enabled supplier involvement) may be a source of competitive advantage, a critical boundary condition for effective collaborative outcomes is interfirm trust (i.e., mutual trust). When alliance partners exchange, combine, invest in idiosyncratic assets, or share sensitive information, they may be exposed to partner firm opportunism, thereby compromising effective cooperation between partners due to perceived risks therein. In the scenario of suppler involvement, for example, the supplier may be concerned about making idiosyncratic investments (e.g., dedicated machinery) which can be used against it by the buying firm in future negotiations; similarly, the buying firm may become vulnerable if the supplier passes the buying firm's sensitive information (e.g., new product technology) along to rival businesses.

In order to realize the competitive advantage of interfirm collaboration (e.g., supplier 
involvement), exchange partners must have effective governance mechanisms. Interfirm trust is arguably the most effective and least costly means of governance that facilitates complex interfirm exchange while minimizing concerns of partner opportunism (Dyer and Singh, 1998). Defined as perceived credibility and benevolence of a target firm, trust has been extensively studied in marketing and other disciplines. A large body of research establishes empirically the various beneficial outcomes of trust. In an interfirm context, for example, trust was found to enhance long-term orientation (Doney and Cannon, 1997), reduce perceived uncertainty and facilitate cooperation (Morgan and Hunt, 1994). In a meta-analysis, Palmatier et al. (2006) confirmed that trust is the single most effective predictor of interfirm cooperation. Mutual trust, in particular, where both parties have a high perceived credibility and benevolence of their counterpart, functions as an especially powerful safeguarding mechanism that promotes information sharing and reduces collaborating firms' tendency to engage in opportunistic behaviors (Fang et al., 2008).

While the great majority of researchers have investigated the positive effects of trust, some have reported negative, albeit counterintuitive effects of trust. For instance, Fang et al. (2008) find that high levels of mutual trust may dampen the joint venture's responsiveness to external change. Selnes \& Sallis (2003) report that interfirm trust may hamper the effect of relational learning on focal firm performance. In a similar vein, Anderson and Jap (2005) suggest that high levels of trust among a cohesive group of contractors led to the loss of innovation due to the removal of external pressure. These findings suggest the "hidden costs" of high levels of interfirm trust, which may be a function of interfirm routine rigidity, cognitive lock-in, and complacency in the status quo. While the potential "dark side" of interfirm trust has been noted in previous research, conditions under which such hidden costs of interfirm trust may outstrip its 
benefits remain largely evasive and unexplored. As McEvily et al. (2003, p. 100) insightfully point out: "Indeed, little systematic research exists on the downside of trust".

\section{Theoretical foundation and hypotheses development}

\subsection{The role of supplier involvement in IT-enabled operations}

According to resource orchestration theory (Chadwick et al., 2015; Hitt et al., 2011;

Sirmon et al., 2011), a limitation of resource-based view (RBV) is that the RBV (Barney, 1991)

focuses on static resources per se and fails to explicate how resources can be deployed

dynamically to produce sustainable competitive advantage. A central tenet of the resource

orchestration theory is that the effect of resource investment on firm performance is mediated by managerial actions in selecting, combining, and leveraging complementary resources, which often entails gaining access to needed resources from partner firms to exploit opportunities (Hitt et al, 2011; Sirmon et al., 2011). That is, "what a firm does with its resources is at least as important as which resources it possesses" (Hansen et al., 2004, p. 1280). This is particularly relevant in the IT-enabled supply chain context because IT infrastructure and investments can easily be duplicated by competitors, which keep IT resources from meeting the RBV criteria of being rare, valuable, non-substitutable, and hard-to-imitate firm-specific resources (Bharadwaj, 2000; Davis \& Golicic, 2010). Noteworthy is that resources can extend beyond the focal firm's boundary, which can be integrated in interfirm routines and operations processes (Das et al, 2006; Lee \& Scott, 2015; Petersen et al., 2003). In particular, when IT infrastructure is used to integrate the focal firm's and its key supplier's resources (e.g., skills and technologies), the learning, bundling, and synchronizing process is socially complex, causally ambiguous, and imperfectly understood by competitors (Bharadwaj, 2000; Das et al., 2006). Therefore, consistent with resource orchestration theory, we argue that IT resources can render sustainable competitive 
advantage when deployed for integrating key suppliers into the focal firm's own business processes.

Supplier involvement entails frequent and timely communication between the focal firm and the supplier (Perols et al., 2013). The focal firm's IT resources can greatly improve the efficiency and effectiveness of supplier involvement, which allows the focal firm to quickly gather and interpret data, to routinize collaborative activities with the supplier, and to continuously exchange time-critical information and learn from one another (Vanpoucke et al., 2014). Supplier involvement can in turn improve idea generation and problem-solving capabilities, resulting in more cost-efficient production and higher quality products during new product design, testing, and commercialization stages (Petersen et al., 2003; Song and Benedetto, 2008), thereby leading to higher focal firm performance. Supplier involvement may also enhance end-user satisfaction as it enables the focal firm to better respond to changing environment (Vanpoucke et al., 2014). Therefore, the focal firm can use its IT resources to effectively bundle and leverage the supplier's expertise and resources to create a competitive advantage, which subsequently leads to improved performance. We hypothesize:

H1: IT resources are positively related to supplier involvement.

$\mathrm{H} 2$ : Supplier involvement is positively related to the focal firm's performance.

IT resources include both physical infrastructure and human elements. Although IT infrastructure per se is unlikely to prevent competitive duplications, the technical and managerial skills needed to develop, implement, and maintain the IT-enabled organizational routines are firm-specific and tacit in nature, are developed over time in a specific context, and are not easily observable and replicable by competitors (Davis \& Golicic, 2010). That is, the tacit knowledge and skills required for running the IT resources can be indeed heterogeneous across competitors, which involve significant experiential learning leading to more sustainable competitive 
advantage (Bharadwaj, 2000). As such, we also expect a direct positive effect of IT resources on the focal firm's performance, in addition to the indirect effect via supplier involvement.

H3: IT resources are positively related to the focal firm's performance.

\subsection{Relational moderator: mutual trust}

Supplier involvement is inherently risky for both the focal firm and the supplier because they must exchange sensitive information, which can make a firm vulnerable to its exchange partner's opportunism and exploitative behaviors (Jean et al., 2014; Narayanan et al., 2015). The relational view of interfirm competitive advantage suggests that the nature of interfirm relationships is not only economic but also socially embedded in buyer-seller interactions (Dyer and Singh, 1998; Ireland et al., 2002). Because interfirm exchange entails unspecified obligations and reciprocity, trust-a form of relational governance-is essential for long-term stable relationships in alleviating concerns of partner opportunism (Cavusgil et al., 2004). Trust reflects a firm's confidence in its exchange partner's reliability and integrity (Morgan \& Hunt, 1994). Importantly, trust must be mutual to be most effective, as unreciprocated trust will quickly lead to instability or dissolution of the relationship (Smith and Barclay, 1999; Yeniyurt et al., 2014). When mutual trust is high, perceived risk of partner opportunism is reduced as both parties keep their counterpart's best interest in mind and refrain from opportunism (Fang et al., 2008; Yeniyurt et al, 2014), and firms will be more willing to share critical and sensitive information with each other (Jap, 1999). Consequently, we expect a stronger positive association of IT resources and supplier involvement when there is a high level of mutual trust between the focal firm and its key supplier.

H4: The positive relationship between IT resources and supplier involvement is stronger when mutual trust is high.

We also expect supplier involvement to have a stronger positive impact on the focal 
firm's performance when mutual trust is high. Supplier involvement entails frequent and close interactions between the focal firm's and the supplier's engineers (Perols et al., 2013), where mutual trust is the "glue" that holds the collaborative relations together (Yeniyurt et al., 2014). Although in general supplier involvement is expected to improve the focal firm's performance, this positive effect will be weaker if mutual trust is lacking, because representatives from one company may not have full confidence in the counterpart's employees' competence and integrity, thereby resisting to adapt their work patterns to accommodate those of their counterpart (Fang et al., 2008). In contrast, high mutual trust lends confidence to the exchange partner's competence and reduces fear of exploitation. Consequently, mutual trust motivates cooperative decision-making and a problem-solving orientation, which will lead to greater firm performance (Fang et al., 2008; Jap, 1999; Yeniyurt et al., 2014).

H5: The positive relationship between supplier involvement and the focal firm's performance is stronger when mutual trust is high.

As stated earlier, IT resources are also expected to have a positive direct effect on the focal firm's performance because IT resources can enhance the focal firm's market-oriented competence (Davis \& Golicic, 2010). In particular, IT resources enable the focal firm to collect market information about end users, suppliers, and competitors (information generation), to distribute relevant market information in a timely fashion to members of the organization who may use it in decision-making (information dissemination), and to implement appropriate strategies by adapting to the constantly changing environment (information use). In order to transform this competence into competitive advantage, however, the focal firm needs its key supplier's full cooperation to accommodate the constantly changing downstream demands and preferences (Wathne \& Heide, 2004). That is, the focal firm cannot successfully tap the full 
potential of its IT resources without gaining adequate support of its key supplier. With high mutual trust, the supplier is more likely to exchange market intelligence, share operations information, and respond quickly to the focal firm's requests, thereby enabling the focal firm to improve its process flexibility, which leads to better market responsiveness and performance.

H6: The positive relationship between IT resources and the focal firm's performance is stronger when mutual trust is high.

\subsection{Environmental moderator: competitive intensity}

Competitive intensity refers to the degree of competition the focal firm faces in the market (Jaworksi \& Kohli, 1993). When competitive intensity is high, companies engage in frequent competitive activities such as price reduction and promotional campaigns, thereby creating market and demand uncertainty. The implication of high competitive intensity is twofolded. On the one hand, from the resource orchestration theory's perspective, using IT capabilities to integrate the key supplier's competence in the focal firm's operations process can create interfirm-specific competitive advantage that wards off intense competitive threat (Hitt et al., 2011; Sirmon et al., 2011), which should motivate IT-enabled supplier involvement. On the other hand, however, when competitive intensity is high, supplier involvement in the focal firm's operations becomes riskier for both parties because partner opportunism will prove more damaging as competitors can quickly erode market share and profits. Therefore, the relational view of the interorganizational competitive advantage would suggest that mutual trust is a critical governance mechanism that alleviates the concerns over partner opportunism (Dyer and Singh, 1998). That is, high competitive intensity will only motive IT-enabled supplier involvement when mutual trust is high because both firms need to have a high level of confidence that their counterpart is willing and able to adapt to the competitive environment while refraining from self-interest seeking behaviors at the expense of the exchange partner 
(Adjei et al., 2009). Therefore, when competitive intensity is high, mutual trust is more critical for IT-enabled supplier involvement. In contrast, when competitive intensity is low, mutual trust becomes less impactful as the perceived risk therein is lower. We expect the following effect:

H7: There is a three-way interactive effect of IT resources, mutual trust, and competitive intensity on supplier involvement such that mutual trust strengthens the positive impact of IT resources on supplier involvement more when competitive intensity is high than when competitive intensity is low.

IT-enabled supplier involvement allows the focal firm to utilize and embed key supplier's resources in its own operations process, which can enhance interfirm relationship predictability due to increased coordination and communications via IT resources (Lee et al. 2012). While mutual trust may enhance interfirm coordination efficiency due to relational norms, mounting evidence also suggests a dark side of trust that can lurk inside otherwise strong relationships (Clercq et al., 2009; Fang et al., 2008; Langfred, 2004; Selnes \& Sallis, 2003; Villena et al, 2011). Specifically, a high level of mutual trust has a strong emotional element to it, which can discourage exchange partners from having constructive debates and healthy task-related conflicts for fear of hurting their counterpart's feelings. Consequently, high mutual trust may hinder interfirm learning due to the groupthink syndrome and the filtering of disparaging viewpoints from outsiders (Selnes \& Sallis, 2003). That is, mutual trust "prevents, rather than encourages, the benefits of task-related disagreements in fostering innovation" (Clercq et al., 2009, p. 293). As Villena et al. (2011) insightfully point out, high levels of trust can produce social liability by reducing a firm's flexibility in decision-making due to obligations and reciprocity with the key supplier. We argue the extent to which the "bright side" or the "dark side" of high mutual trust manifests in IT-enabled supplier involvement depends on competitive intensity.

IT-enabled interfirm integration enhances relationship stability, which is further strengthened by routinized norms and behavioral patterns bred by high interfirm trust (Lee et al. 
2012). In an environment where competitive intensity is low, the benefits of high mutual trust will likely dominate because there is little need to disrupt and revamp routines. However, when competitive intensity is high, routine rigidity and cognitive lock-in bred by high mutual trust can impede firm performance. Indeed, resource orchestration theory suggests that the value of stable interfirm routines and capabilities quickly diminishes as competitive rivalry intensifies (Sirmon et al, 2011). The tendency for mutual trust to create routine rigidity is particularly high in interfirm relationships where formal mechanisms and procedures are in place to facilitate partner integration (Das et al., 2006; Fang et al., 2008). In supplier involvement, employees of the customer and the supplier firms must collectively participate in the formal decision-making process and frequently coordinate their activities, which will more likely give rise to routine rigidity and relational inertia especially when mutual trust is high (Fang et al., 2008).

Moreover, high mutual trust may create a cognitive lock-in that isolates bonded parties from the outside world because both parties think it unnecessary to adjust established routines and procedures, causing poor responsiveness to environmental changes (Anderson \& Jap, 2005; Fang et al., 2008). The dark side of mutual trust may become more manifest and disruptive in a highly competitive market, where mutual trust can significantly reduce the focal firm's ability and speed to adapt to the fast-changing competitive environment. In comparison, a low level of competitive intensity is likely to mask the dark side of mutual trust due to little need for swift adaptations to counter the competitive moves (Sirmon et al., 2011).

H8: There is a three-way interactive effect of supplier involvement, mutual trust, and competitive intensity on the focal firm's performance such that mutual trust significantly strengthens the positive impact of supplier involvement on the focal firm's performance only when competitive intensity is low.

Although high mutual trust may negatively affect the effect of supplier involvement in a 
highly competitive environment, mutual trust can actually enhance the direct positive effect of IT resources on the focal firm's performance when competitive intensity is high. When the focal firm employs its IT resources to facilitate the decision-making and implementation processes independent of its key supplier, the supplier is more distal from the focal firm, which significantly simplifies the coordination process and thwarts the development of detrimental cognitive lock-in and routine rigidity typically found in integrated interfirm relationships (Fang et al, 2008). As the environment becomes more competitive, IT resources enable the focal firm to effectively generate, disseminate, and analyze market-oriented intelligence (Davis \& Golicic, 2010).

Still, to act on the IT-enabled market intelligence with high efficiency, the focal firm needs the supplier's full cooperation to implement appropriate product and marketing strategies in a timely fashion (Wathne \& Heide, 2004). A lack of mutual trust can substantially compromise the efficacy of the focal firm's IT resources in adapting to a highly competitive market (Morgan \& Hunt, 1994). Moreover, suppliers can serve as a source for competitive intelligence, a critical resource that can be accessed and utilized by the focal firm to significantly improve the focal firm's market responsiveness (Adjei et al., 2009). However, the focal firm can only turn its IT resources into a powerful tool in collecting, disseminating, analyzing, and responding to market intelligence when there is a high level of mutual trust between both parties, as the supplier is more willing to put its own resources to support the focal firm's initiative. When competitive intensity is low, mutual trust becomes less impactful as the need to collect and respond to fast-changing market intelligence is much lower. Therefore, we argue that the benefits of mutual trust will likely outweigh its "hidden costs" in a competitive market when IT resources are employed without the direct participation of the key supplier in the focal firm's business 
processes.

H9: There is a three-way interactive effect of IT resources, mutual trust, and competitive intensity on the focal firm's performance such that mutual trust significantly strengthens the positive impact of IT resources on the focal firm's performance only when competitive intensity is high.

\section{Methods}

\subsection{Sample and data collection}

To test our model, we collected data from the manufacturing sector in China. China is an appropriate empirical setting since its large manufacturing base accounts for more than a quarter of the world's total manufacturing output and supplier involvement in downstream customers' operations is commonplace (Euromonitor, 2012). The survey instrument was first drafted in English and then translated into Chinese according to the established back-translation procedures (Brislin, 1980). We conducted in-depth interviews with a small group of sales and procurement executives to gain further understanding of the research context, based on which necessary modifications to the surveys were made. We collected data from two different informants in each firm in an effort to minimize common method bias (Podsakoff, MacKenzie, \& Podsakoff, 2012). In each firm, one informant identified a key supplier based on the importance and volume of the procurement and provided data on IT resources, mutual trust, and supplier involvement accordingly, while the other informant reported on firm performance, competitive intensity, and product complexity (a covariate that we incorporated in the empirical model).

We obtained a representative list of 3,000 manufacturing firms from a Chinese professional research company, from which we randomly selected 500 firms and contacted the top management for their participation; 235 firms agreed to respond and provided useful data via face-to-face interviews, for a response rate of $47 \%$. The informants were top-level executives 
with broad organizational responsibilities in marketing, procurement, operations, and supply chain, who had access to firm-level information. These firms in the sample represented industries including machinery and metal fabrication, computer and electronics, automobile and parts, biotechnology and pharmaceuticals, chemicals, among others. Annual firm sales in the past year were between 10 million and 4.5 billion RMB yuan (US $\$ 1.5$ million to 670 million), with a median sales revenue of 200 million yuan (US\$29 million). The number of employees ranged from 30 to more than 100,000, with a median of 1,600. We compared firm sizes (logarithm of sales revenues and number of employees) of the responding and non-responding firms via t-tests and found no significant differences, suggesting non-response bias was not likely a problem.

\subsection{Measures}

We assessed IT resources with four items adapted from Davis \& Golicic (2010). Consistent with the definition of IT resources, these items assess the extent to which the focal firm has made investments in IT infrastructure as well as competence of deploying IT resources in its operations. Four items were adapted from Primo \& Amundson (2002) for measuring supplier involvement, which assess the degree to which the focal firm engages its key supplier in its product development and operations processes. Mutual trust was measured with four items adapted from Jap (1999) assessing the extent of mutual reliability and integrity perceived in the relationship as a whole from the focal firm's perspective. Due to budgetary and other challenges in collecting dyadic data from both the manufacturing firms and their key suppliers, we could not measure mutual trust by aggregating the scores of both exchange partners, which we acknowledge as a caveat when interpreting our results and will discuss this issue again in the limitation section. We note, however, if the manufacturing firms had any systematic tendencies to inflate or deflate their perceived suppliers' trust in them, the resultant lower variance in mutual 
trust would make it much more difficult for us to find significant two-way and three-way interactions. The fact that we uncover these interactive effects somewhat alleviated this concern. Moreover, this measurement approach appears to be consistent with marketing studies in similar contexts (Fang et al., 2008; Jap, 1999), which essentially assessed the extent to which the focal firm believes both parties trust each other.

Competitive intensity was measured with four items from Jaworski and Kohli (1993) evaluating the number of competitors and degree of competitive activities in the focal firm's market. These constructs were measured on 7-point Likert scales $(1=$ "strongly disagree" to $7=$ "strongly agree").

We used relative measures of firm performance to overcome the difficulty of comparing performances across industries and firms. In accordance with previous research (Slater \& Narver 1994; Vorhies \& Morgan, 2005), we assessed firm performance in terms of sales growth, profit growth, profitability, and return on investment over the past 3 years. The anchors were $1=$ "much worse than major competitors" and $7=$ "much better than major competitors."

Finally, we incorporated two covariates ${ }^{1}$ when empirically testing the model, namely product complexity and firm size, to control for the heterogeneity of firms across industries and markets. Product complexity was measured with 2 items adapted from (Fang, 2008) to assess the degree to which the product is technologically complex and sophisticated. We measured firm size in terms of sales revenue in the previous year, and we took its natural logarithm to remedy

\footnotetext{
${ }^{1}$ Per a reviewer's request, we also included other covariates such as industry, firm age, and the firm's ownership structure (state owned, private owned, public traded, collective, foreign, or Sino-foreign joint-venture) in a separate regression. The model results are essentially identical. Because there is no change for the statistical significance of the parameter estimates, we only report results based on these two covariates to save space but the aforementioned results of a separate regression model are available upon request.
} 
skewness in the data. All multi-item scales, along with their internal consistency estimates are presented in Appendix A.

\section{Results and discussion}

\subsection{Measurement model}

We assessed the measurement model with a confirmatory factor analysis. The measurement model with six latent constructs and 22 indicators exhibited acceptable fit: $\chi^{2}=$ $388.45(\mathrm{df}=194), \mathrm{RMSEA}=.065, \mathrm{NNFI}=.95$, and $\mathrm{CFI}=.96$. Item loadings were all significant and positive on their a priori constructs, and no significant cross-loadings were observed, suggesting convergent validity and unidimensionality of the latent constructs (Anderson \& Gerbing, 1988). In addition, average variance extracted (AVEs) ranged from .57 to .73, and both Cronbach's alphas and composite reliability measures were above .80 for all constructs, demonstrating internal reliability (Bagozzi \& Yi, 1988).

For discriminant validity, we compared the squared correlations with the AVEs of all pairs of latent constructs and found that no squared correlation exceeded the average AVE (Fornell \& Larcker, 1981). We also conducted a series of Chi-square tests, comparing an unconstrained measurement model where the correlation between a pair of constructs was freely estimated and a constrained model where the correlation was set to one, and the unconstrained model always fit the data significantly better (Anderson \& Gerbing, 1988).

Finally, because the data involving IT resources, mutual trust, and supplier involvement came from one informant and the second informant reported on firm performance, competitive intensity, and product complexity (i.e., single source), there may be a concern of common method variance (CMV). We conducted a series of test to assess CMV. First, we used Harman's single factor test through an exploratory factor analysis (EFA) which included all 22 items of the 
six variables. A clear six-factor structure emerged, which explained $78.02 \%$ of the variance. The first component explained only $31.17 \%$ of the total variance. Second, we compared in SEM the hypothesized six factor-model with a one-factor model and a two-factor model (where each factor has three variables and represents the corresponding informant who provided data on these three variables). The results show that the six-factor model was a much better fit $\left(\chi^{2}=388.45\right.$, df $=194)$ than the single-factor model $\left(\chi^{2}=2706.02, \mathrm{df}=209\right)$ and the two-factor model $\left(\chi^{2}=\right.$ 2498.42, df = 208). Third, we followed Williams, Hartman, \& Cavazotte (2010) to conduct a series of SEM-based tests using a marker variable (i.e., CEO leadership style) approach. Again, results indicate that interrelationships among latent variables were not affected by CMV. These results, together with the fact that significant two-way and three-way interactions that we found in the data cannot be artifacts of CMV (Siemsen et al., 2010), suggest that CMV is not likely an issue in our study.

Therefore, acceptable psychometric properties for all latent constructs were established. Table 1 presents the descriptive statistics for all variables in the model.

-- Table 1 about here --

\subsection{Hypothesis testing}

Hypothesis testing was conducted with a series of hierarchical regression models for supplier involvement and focal firm's performance, respectively. In both cases, we entered the two control variables first, followed by the main effect variables, and finally, the interaction terms. All variables were mean-centered before the interaction terms were computed. Tables 2 and 3 present the unstandardized regression coefficients, their $\mathrm{t}$-values, and the model $\mathrm{R}^{2}$ estimates.

-- Table $2 \& 3$ about here -- 
Hypotheses 1-3 predict the indirect and direct effects of IT resources on focal firm's performance via supplier involvement. In particular, H1 proposes that IT resources are positively related to supplier involvement. As the Model 3 column of Table 2 shows, the relationship is found to be positive and significant $(b=.101, \mathrm{p}<.05)$, in support of $\mathrm{H} 1 . \mathrm{H} 2$ predicts that supplier involvement is positively related to the focal firm's performance. As the Model 3 column of Table 3 shows, this hypothesis is supported $(b=.330, t=4.384, \mathrm{p}<.01)$. H3, which proposes a positive relationship between IT resources and the focal firm's performance, is also supported (Table $3: \mathrm{b}=1.28, \mathrm{t}=2.146, \mathrm{p}<.05$ ). Thus, H1-3 are fully supported, which illustrate the partial mediation role of supplier involvement in the focal firm's IT-enabled operations.

Hypotheses 4-6 are concerned with two-way interactions involving mutual trust. In particular, H4 suggests that the positive relationship between IT resources and supplier involvement is stronger when mutual trust is high. This hypothesis is supported as the coefficient (see Table 2) for the IT-trust interaction on supplier involvement is positive and significant $(b=.118, \mathrm{p}<.05)$. H5, which posits that the positive relationship between supplier involvement and focal firm's performance is stronger when mutual trust is high, is also supported given the positive and significant involvement-trust interaction on performance (Table $3: \mathrm{b}=.104, \mathrm{p}<.05)$. Lastly, the positive relationship between IT resources and focal firm's performance is evidently stronger when mutual trust is high $(b=.223, \mathrm{p}<.01)$, in support of H6. As such, H4-6 are fully supported.

Hypotheses 7-9 suggest more complex three-way interactive effects. More specifically, H7 proposes that mutual trust strengthens the positive impact of IT resources on supplier involvement more when competitive intensity is high than when it is low. However, as presented in Table 2, the coefficient estimate for the 3-way interaction term is not statistically significant (b 
$=-.015, \mathrm{~ns})$, and therefore this hypothesis is not supported. H8 posits that mutual trust significantly strengthens the positive impact of supplier involvement on performance only when competitive intensity is low. Table 3 shows a statistically significant coefficient estimate for the three-way interaction $(b=-.132, \mathrm{p}<.01)$. To help interpret this finding, we plot the simple slope graphs in Figure 2 using the unstandardized regression coefficients with one standard deviation above and below the mean values of the moderators. The figure shows that when competitive intensity is low, the positive supplier involvement-performance relationship is the strongest at high level of trust, whereas when competitive intensity is high, the strength of the supplier involvement-performance relationship is virtually the same regardless of the level of mutual trust. This finding is in complete agreement with the prediction of $\mathrm{H} 8$.

-- Figure 2 about here --

Finally, H9 proposes a three-way interactive effect of IT resources, mutual trust, and competitive intensity on the focal firm's performance such that mutual trust significantly strengthens the positive impact of IT resources only when competitive intensity is high. Consistent with H9, the coefficient estimate for the three-way interaction is positive and significant $(b=.137, \mathrm{p}<.01)$. The simple slope plots in Figure 3 show that when competitive intensity is high, IT resources have a dramatically different relationship with the focal firm's performance across different levels of mutual trust. Specifically, when competitive intensity is high, IT resources have the strongest positive effect on the focal firm's performance when mutual trust is high. When mutual trust is low, however, IT resources actually have a negative effect on the focal firm's performance. In contrast, the moderating effects of mutual trust are not nearly as pronounced when competitive intensity is low (see Figure 3). Therefore, H9 is fully supported. 
-- Figure 3 about here -

\subsection{Research implications}

While it is a widely held belief that both IT resources and supplier involvement can build competitive advantage for the focal firm, empirical results have been inconclusive. Some researchers have suggested that IT resources can only provide limited competitive advantage because competitors can easily duplicate tangible IT infrastructure (Bharadwaj, 2000; Davis \& Golicic, 2010). Moreover, few studies have explicitly investigated the role of supplier involvement in the IT-enabled operations, although suppliers are being increasingly integrated in the buying firms' operations (Menguc et al., 2014; Yeniyurt et al., 2014). By investigating the moderated mediation role of supplier involvement, our study sheds light on two important research questions identified in the introduction section: (1) To what extent do IT resources create value by integrating the key supplier in the focal firm's operational processes? (2) Under what conditions will supplier involvement lead to improved performance?

According to resource orchestration theory, firms can build competitive advantage by deploying their own resources in combination with other complementary resources that maximize the value-creation potential of the focal firm's resources (Chadwick et al., 2015; Hitt et al, 2011; Sirmon and Hitt, 2009). This resource synchronization process requires efficient information exchange and utilization that provides a rich interfirm learning context, which facilitates the bundling and configuration of complementary resources and skills (Hitt et al, 2011). Consistent with the resource orchestration theory, our results indicate that the effect of IT resources on the focal firm's performance is not entirely direct but is also indirect via supplier involvement. Supplier involvement provides insight, knowledge, skills, and experience the focal firm needs in order to improve market performance (Menguc et al., 2014). As engineers from 
both the focal firm and the key supplier collaborate closely, they engage in a learning process that requires immediate and frequent communication for effective resource combination and reconfiguration (Perols et al., 2013; Vanpoucke et al., 2014). It is in this context that the focal firm's IT resources can play a critical role in integrating the supplier's resources by facilitating information exchange, analysis, and learning. Moreover, IT resources can enable the development of interfirm organizational routines that are context specific, valuable to both firms, socially complex, and imperfectly understood by competitors (Chadwick et al, 2015). Therefore, the focal firm's IT resources become more valuable when integrated with the supplier's resources during supplier involvement, which create non-substitutable interfirm synergies that lead to superior firm performance (Das et al, 2006).

Although supplier involvement partially mediates the positive effect of IT resources on focal firm's performance, there are conditions under which the effect of supplier involvement may be amplified or mitigated in the IT-enabled environment. According to the relational view of interfirm competitive advantage (Dyer and Singh, 1998), supplier involvement is an interfirm behavior that is not only economic but also is socially embedded and relational in nature. The relational view of interfirm exchange considers interfirm relationship as a dynamic process in which both parties are expected to carry out reciprocal activities directed toward one another (e.g., mutual adaptation) in exchanging valuable resources (Hallen et al., 1991). To the extent that IT-enabled supplier involvement entails the sharing of sensitive information, both the focal firm and the key supplier may have concerns over potential partner opportunism and exploitative behavior, thereby refraining from using IT resources for interfirm communication and resource exchange (Das et al., 2006).

As such, to tap the full potential of IT resources, the focal firm must develop a highly 
collaborative relationship with the supplier characterized by high mutual trust, which is the "glue" that holds collaborative relations together (Dyer and Singh, 1998; Ireland et al., 2002; Yeniyurt et al., 2014). As a potent relational governance against opportunism, mutual trust enhances both parties' confidence that their partner is credible and benevolent and will not abuse sensitive information exchanged (Cavusgil et al, 2004). Indeed, our results illustrate that the positive effect of IT resources on supplier involvement is strengthened when there is a high level of mutual trust. Moreover, we find that supplier involvement has a much stronger positive effect on focal firm's performance when both parties trust each other, because mutual trust effectively enhances both parties' willingness to cooperate (Morgan and Hunt, 1994; Palmatier et al., 2006).

Mutual trust is also found to amplify the direct effect of IT resources on focal firm's performance when the key supplier is not directly involved in the focal firm's product design and operations process. IT resources enable the focal firm to effectively collect, analyze, and disseminate market information (Davis \& Golicic, 2010). However, to effectively implement competitive strategies based on market-based information, the focal firm must have the supplier's full support (Wathne \& Heide, 2004). Toward that end, a high level of mutual trust can not only motivate the supplier to share competitive information but also effective ly coordinate with the focal firm to offer products and services that meet customers' needs and preferences (Adjei et al., 2009).

Despite the overwhelmingly positive moderation effects of mutual trust in all two-way interactions, we find that the "hidden costs" of mutual trust will likely become manifest in supplier involvement under high competitive intensity. Conversely, mutual trust amplifies the positive direct effect of IT resources on the focal firm's performance when the supplier is not directly involved in the focal firm's decision-making and operations processes. These opposite 
findings suggest that supplier involvement will not pay off across all situations and that mutual trust is likely a double-edged sword in affecting the relative effects of IT resources vis-à-vis supplier involvement on the focal firm's performance.

Although the relational view of interfirm competitive advantage (Dyer and Singh, 1998) suggests that mutual trust is a precondition for cooperative activity, the focus on the positive side of mutual trust in interfirm relationships tends to "blind us to the considerable downside of trust" (McEvily et al., 2003, p. 99). In a similar vein, Villena et al. (2011) warn that trust may at times produce social liability because the focal firm may lose flexibility and independence in its decision-making. When the focal firm and its supplier work together like a co-entity, high mutual trust between them tends to build self-reinforcing routine rigidity, keep both parties from exchanging negative information and searching for external information, and create cognitive lock-in, all of which may hamper innovation and responsiveness (Clercq et al., 2009; Fang et al., 2008; Selnes \& Sallis, 2003). These "hidden costs" of high mutual trust become much more pronounced when the focal firm's market is highly competitive where competitors make frequent changes in their product and/or marketing strategies, which would require interfirm collaboration to modify or even abandon established routines (Sirmon et al., 2011). However, mutual trust tends to breed routine rigidity and cognitive inertia (Anderson and Jap, 2005; Fang et al., 2008), which makes it difficult for the trusting collaborating firms to quickly adapt to the changing environment. To the extent that IT integration formalizes predictable interfirm behavioral patterns (Lee et al. 2012), high mutual trust can solidify cognitive heuristics embedded in supplier involvement leading to systematically biased judgements (McEvily et al., 2003). Indeed, our results corroborate this argument by showing that mutual trust significantly weakens the positive impact of supplier involvement on the focal firm's performance when competitive 
intensity is high.

In contrast, keeping the supplier at a more distal position (i.e., without supplier involvement) when the focal firm's market is highly competitive proves to be beneficial, especially when there is a high level of mutual trust. We argue that when the focal firm is able to make independent product design and operational decisions, the bright side of trust is likely to overshadow the dark side because interfirm routine rigidity and cognitive lock-in are less likely to form; in the meantime, the supplier is responsive and supportive of the focal firm's initiatives, and is willing to make necessary adaptations to accommodate the focal firm's strategies (Morgan and Hunt, 1994). Therefore, IT resources will likely enable the focal firm to adapt more quickly and effectively to the changing environment when both parties trust each other.

\subsection{Limitations and future research directions}

Like all other research, our study is subject to some limitations. First, although we collected data for predictor and criterion variables from two different informants, they came from the same company. A better approach may be to collect longitudinal objective performance data. Second, our sample came from the manufacturing sector in China. The extent to which results can be replicated in other contexts cannot be assumed without further empirical investigations. Third, as we mentioned in the measurment section, the measure of mutual trust was not an aggregate score of both the manufacturer's trust in the supplier and the supplier's trust in the manufacturer. That is, results regarding the moderating role of mutual trust should be interpreted with caution. What we essentially measured was the manufacturer's perceived total dyadic trust between itself and the supplier. Because the supplier's trust was perceived by the manufacturer,

there could be some systematic upward or downward bias in the manufacturers' reponses. Although this measurement approach has been used by researchers in similar marketing studies 
(Fang et al. 2008; Jap 1999), future studies should collect dyadic data to allow for a more rigorous test for mutual trust.

Our study also poitns out directions for future research. First, we find that the dark side of mutual trust sets in for supplier involvement when competitive intensity is high. The literature suggests that the "hidden costs" of trust are due to groupthink, filtering of external information, cognitive lock-in, and routine rigidity (Fang et al,, 2008; Selnes \& Sallis, 2003). Future research can explicitly examine these factors as well as potential countermeasures to mitigate their negative influence on the efficacy of supplier involvement. Second, in contrast to its negative moderation effect on the supplier involvement-performance association in competitive markets, mutual trust has a positive moderation effect on the direct IT-performance link. As supplier involvement only partially mediates the effect of IT resources on focal firm's performance, an exploration of the full underlying mechanisms would further our understanding of the effects of IT resources.

Moreover, some researchers distinguish interfirm trust from interfirm reliance and suggest that the latter may be more influential in deteriming interfirm performance outcomes (Jiang et al., 2011) ${ }^{2}$. Future studies can use reliance as a moderator in IT-enabled supplier involvement and compare its effects with those of interfirm trust. Finally, we operationalized supplier involvement as a global construt. However, researchers have suggested that the nature or content of supplier involvement also matters. For example, supplier involvement can take the form of process integration, product integration, or other types of intergation (Perols et al, 2013; To, 2016). A supplier can serve mainly as a co-producer or as an information provider during the new product design and development process (Fang, 2008). It has yet to be determined whether

\footnotetext{
2 We thank an anonymous reviewer for this insight.
} 
the relationships in our model will vary when a more refined operationalization of supplier involvement is employed. These intriguing questions can only be answered by future research.

\section{Conclusion}

This study makes important contributions to the literature by addressing two research questions set forth in the beginning of the paper. First, consistent with the resource orchestration theory and the relational view of interfirm competitive advantage, our study finds strong evidence that IT resources can have a positive effect on the focal firm's performance via the partial mediation role of supplier involvement. Therefore, it appears that involving the key supplier in the focal firm's operations process using IT resources can create synergistic interfirm competitive advantage leading to improved performance. Perhaps more importantly, our research also identifies conditions under which the positive effect of supplier involvement may be strengthened or compromised. While mutual trust can generally enhance the positive mediation effect of supplier involvement when competitive intensity is low, mutual trust can actually render supplier involvement an ineffective resource orchestration strategy due to the "hidden costs" of mutual trust in highly competitive markets. In a highly competitive environment, the focal firm can fare better without involving an otherwise trusting supplier in its operations process, which helps dodge the "dark side" while benefiting from the "bright side" of high mutual trust. These findings not only enhance our understanding of the contingent role of supplier involvement in IT-enabled operations, but also enrich theory building by highlighting some of the contingencies in the resource orchestration theory and the relational view of interfirm competitive advantage. 
Table 1: Descriptive statistics

\begin{tabular}{|l|c|c|c|c|c|c|c|c|}
\hline & Mean & $\begin{array}{c}\text { Std } \\
\text { Dev }\end{array}$ & 1 & 2 & 3 & 4 & 5 & 6 \\
\hline 1. IT resources & 4.63 & 1.08 & - & & & & & \\
\hline 2. Mutual trust & 4.95 & .97 & .27 & - & & & & \\
\hline 3. Competitive intensity & 4.62 & 1.03 & .29 & .27 & - & & & \\
\hline 4. Supplier involvement & 4.88 & 1.11 & .32 & .58 & .43 & - & & \\
\hline $\begin{array}{l}\text { 5. Focal firm's } \\
\text { performance }\end{array}$ & 5.09 & .95 & .29 & .25 & .09 & .34 & - & \\
\hline 6. Log (annual sales) & 12.13 & 2.03 & .13 & .13 & .17 & .01 & .04 & - \\
\hline 7. Product complexity & 4.45 & 1.47 & -.05 & .09 & -.09 & -.10 & -.02 & .23 \\
\hline
\end{tabular}

*Correlations above .12 are significant at .05 .

Table 2: Moderated effects on supplier involvement

\begin{tabular}{|l|c|c|c|c|c|c|}
\hline & \multicolumn{2}{|c|}{$\begin{array}{c}\text { Model 1 } \\
\text { (Control Only) }\end{array}$} & \multicolumn{2}{c|}{$\begin{array}{c}\text { Model 2 } \\
\text { (Main Effect) }\end{array}$} & \multicolumn{2}{c|}{$\begin{array}{c}\text { Model 3 } \\
\text { (Interaction Effect) }\end{array}$} \\
\hline & $\mathrm{b}$ & $\mathrm{t}$-value & $\mathrm{b}$ & $\mathrm{t}$-value & $\mathrm{b}$ & $\mathrm{t}$-value \\
\hline Constant & .000 & .002 & .000 & -.001 & .039 & .718 \\
\hline Ln(annual sales) & .017 & .457 & -.052 & -1.843 & -.038 & -1.420 \\
\hline Product complexity & -.078 & -1.539 & -.065 & -1.671 & -.093 & -2.512 \\
\hline IT resources & & & .126 & 2.320 & .101 & 1.873 \\
\hline Mutual trust & & & .556 & 9.211 & .532 & 9.127 \\
\hline $\begin{array}{l}\text { Competitive intensity } \\
\text { (CI) }\end{array}$ & & & .290 & 5.031 & .311 & 5.328 \\
\hline IT*Trust & & & & & .118 & 1.934 \\
\hline IT*CI & & & & & .010 & .199 \\
\hline Trust*CI & & & & & -.288 & -5.305 \\
\hline IT*CI*Trust & & & & & -.015 &.- .421 \\
\hline R2 & .002 & & .442 & & .518 & \\
\hline Sig F Change & .307 & & .000 & & .000 & \\
\hline
\end{tabular}


Table 3: Moderated effects on focal firm's performance

\begin{tabular}{|l|c|c|c|c|c|c|}
\hline & \multicolumn{2}{|c|}{$\begin{array}{c}\text { Model 1 } \\
\text { Control Only) }\end{array}$} & \multicolumn{2}{c|}{$\begin{array}{c}\text { Model 2 } \\
\text { (Main Effect) }\end{array}$} & \multicolumn{2}{c|}{$\begin{array}{c}\text { Model 3 } \\
\text { (Interaction Effect) }\end{array}$} \\
\hline & $\mathrm{b}$ & $\mathrm{t}$-value & $\mathrm{b}$ & $\mathrm{t}$-value & $\mathrm{b}$ & $\mathrm{t}$-value \\
\hline Constant & .000 & .001 & .000 & .000 & -.116 & -1.802 \\
\hline Ln(annual sales) & .020 & .620 & .007 & .227 & .006 & .191 \\
\hline Product complexity & -.016 & -.373 & .003 & .076 & -.016 & -.384 \\
\hline IT resources & & & .191 & 3.308 & .128 & 2.146 \\
\hline Mutual trust & & & .057 & .769 & .162 & 2.077 \\
\hline $\begin{array}{l}\text { Competitive intensity } \\
\text { (CI) }\end{array}$ & & & -.100 & -1.571 & -.061 & -.881 \\
\hline IT*Trust & & & & & .223 & 3.330 \\
\hline IT*CI & & & & & -.130 & -2.199 \\
\hline Trust*CI & & & & & .064 & .889 \\
\hline IT*CI*Trust & & & & & .137 & 2.473 \\
\hline Involvement (INV) & & & .241 & 3.462 & .330 & 4.384 \\
\hline INV*Trust & & & & & .104 & 1.794 \\
\hline INV*CI & & & & & -.061 & -.838 \\
\hline INV*CI*Trust & & & & & -.132 & -2.969 \\
\hline R2 & & & .164 & & .266 & \\
\hline Sig F Change & .803 & & .00 & & .00 & \\
\hline
\end{tabular}


Appendix A: Multi-item measurement scales

IT resources $\left(\alpha=.87 ; \mathrm{AVE}=.63 ; \rho_{\mathrm{c}}=.87\right)$

1. Our company actively searches out and acquires state-of-the-art information technology.

2. Our company uses state-of-the-art information technology to communicate and share information with the key supplier.

3. Our company has the knowledge and skills needed to maintain the best information technology system.

4. Our company's information system enables us to share business data for improving our market knowledge across all business units.

Mutual trust $\left(\alpha=.91 ; \operatorname{AVE}=.73 ; \rho_{c}=.91\right)$

1. The key supplier and our firm consider each other's interests when problems arise.

2. The promises the key supplier and our firm make to each other are reliable.

3. The key supplier and our firm are very honest in dealing with each other.

4. The key supplier and our firm trust each other.

Competitive intensity $\left(\alpha=.82 ; \mathrm{AVE}=.57 ; \rho_{\mathrm{c}}=.84\right)$

1. Competition in our industry is cutthroat

2. Price competition is a hallmark of our industry

3. One hears of a new competitive move almost every day.

4. There are many competitors in our target market.

Supplier involvement $\left(\alpha=.89 ; \mathrm{AVE}=.68 ; \rho_{\mathrm{c}}=.89\right)$

1. Our company has involved the key supplier in our product development process.

2. The key supplier participates in our product development process.

3. Our company asks for the key supplier's input for continuous improvement in our operations.

4. We work with the key supplier to improve our products and services.

Focal firm's performance (Performance in the past three years) $\left(\alpha=.91\right.$; AVE $=.71 ; \rho_{\mathrm{c}}$ $=.91)$

1. Sales growth

2. Profit growth

3. Profitability rate

4. Return of investment (ROI)

Product complexity $\left(\alpha=.91 ; \mathrm{AVE}=.73 ; \rho_{\mathrm{c}}=.84\right)$

1. Our products are technically complicated.

2. Our products apply advanced/sophisticated technology. 
Figure 1: Conceptual model

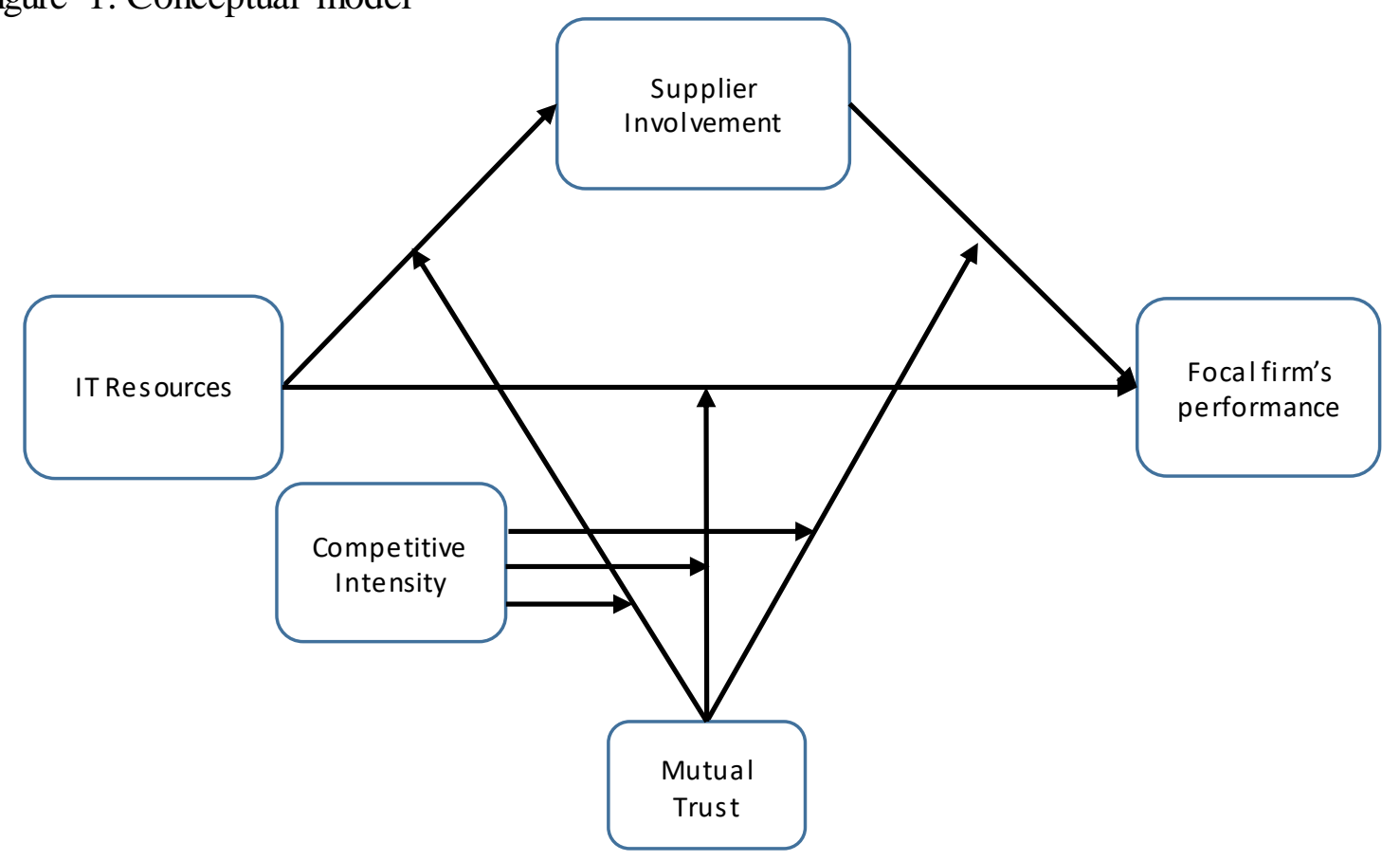

Figure 2: The moderation effects of mutual trust and competitive intensity on the relationship between supplier involvement and focal firm's performance

A. Low competitive intensity

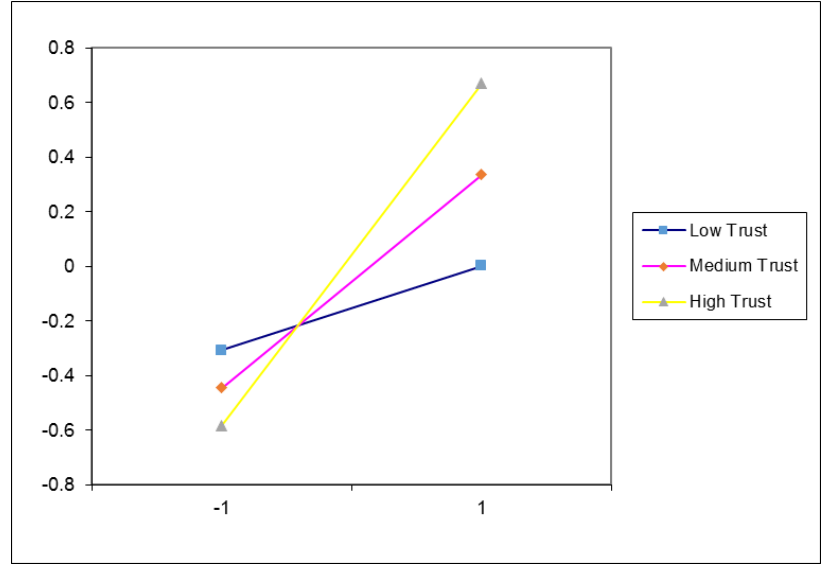

B. High competitive intensity

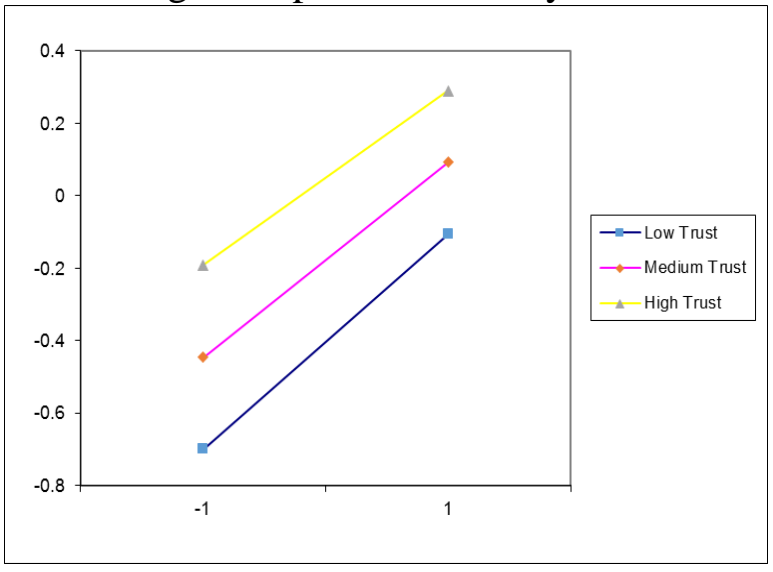


Figure 3: The moderation effects of mutual trust and competitive intensity on the relationship between IT resources and focal firm's performance

A. Low competitive intensity

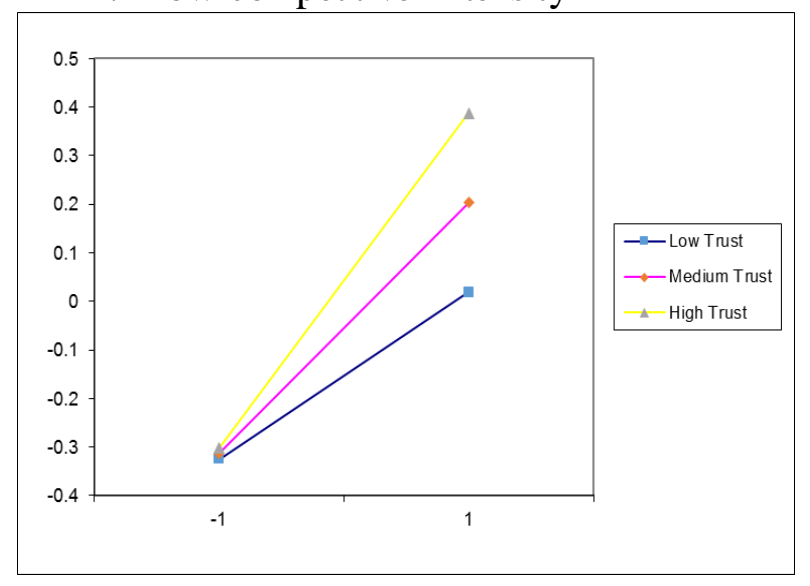

B. High competitive intensity

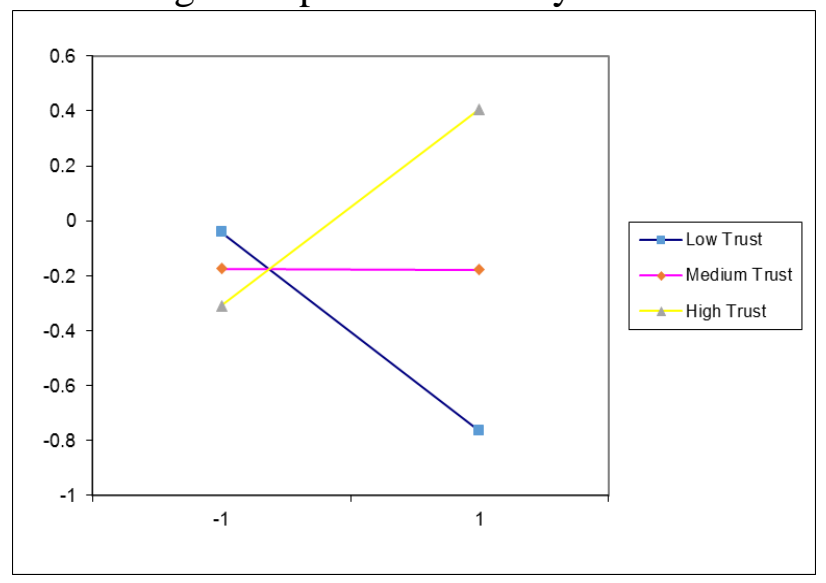




\section{References}

Adjei, M., Griffith, D., \& Noble, S. (2009). When do relationships pay off for small retailers? Exploring targets and contexts to understand the value of relationship marketing. Journal of Retailing, 85 (4), 493-501.

Afuah, A.N. (2000). How much do your co-optetiors' capabilities matter in the face of a technological change? Strategic Management Journal, 21, 387-404.

Anderson, J. C., \& Gerbing, D. W. (1988). Structural equation modeling in practice: A review and recommended two-step approach. Psychological Bulletin, 103(3), 411-423.

Anderson, E. \& Jap, S. (2005). The dark side of close relationships. Sloan management Review 46 (3), $75-$ 82.

Bagozzi, R. P., \& Yi, Y. (1988). On the evaluation of structural equation models. Journalof the Academy of Marketing Science, 16(1), 74-94.

Barney, J.B. (1991). Firm resources and sustained competitive advantage. Journal of Management, 17, 99-120.

Bharadwaj, A. (2000). A resource-bsed perspective on information technology capability and firm performnce: an empirical investigation. MIS Quarterly, 24(1), 169-196.

Brislin, R. W. (1980). Translation and content analysis of oral and written materials. In H. C. Triandis \& J. W. Berry (Eds.), Handbook of cross-cultural psychology (Vol. 2, pp. 389-444). Boston: Allyn \& Bacon.

Brynjolfsson, E., \& Hitt, L. M. (1998). Beyond the productivity paradox. Communications of the ACM, 41(8), 49-55.

Carr, A. S., \& Pearson, J. N. (2002). The impact of purchasing and supplier involvement on strategic purchasing and its impact on firm's performance. International Journal of Operations \& Production Management, 22(9), 1032-1053.

Cavusgil, S., Deligonul, S., \&Zhang, C. (2004). Curbing foreign distributor opportunism:an examination of trust, contracts, and the legal environment in international channel relationships. Journalof InternationalMarketing, 12 (2), 7-27.

Chadwick, C., Super, J.F., \& Kwon, K. (2015). Resource orchestration in practice: CEO emphasis on SHRM, commitment-based HR systems, and firm performance. Strategic Management Journal, 36 (3), 360-376.

Clercq, D., Thongpapanl, N., \& Dimov, D. (2009). When good conflict gets better and bad conflict becomes worse: the role of social capital in the conflict-innovation relationships. Journal of the Academy of Marketing Science, 37, 283-297.

Das, A., Narasimhan, R., \& Talluri, S. (2006). Supplier integration - finding an optimal configuration. Journalof Operations Management, 24, 563-582.

Davis, D. F., \& Golicic, S. L. (2010). Gaining comparative advantage in supply chain relationships: The mediating role of market-oriented it competence. Journal of the Academy of Marketing Science, 38, 56-70.

Doney, P. M. and Cannon, J. P. (1997). An Examination of the Nature of Trust in Buyer-Seller Relationships. Journal of Marketing, 61 (April), 35-51.

Dong, S., Xu, S., \& Zhu, K. (2009). Information technology in supply chains: the value of IT-enabled resources under competition. Information Systems Research, 20 (1), 18-32.

Dyer, J. H. and Singh, H. (1998). The Relational View: Cooperative Strategy and Sources of Interorganizational Competitive Advantage. Academy of Management Review, 23 (4), 660-679.

Euromonitor. (2012). China leads global manufacturing output http://blog.euromonitor.com/2012/01/china-leads-global-manufacturing-output-.html. Retrieved January 22, 2012 
Fang, E. (2008). Customer participation and the trade-off between new prodcut innovativeness and speed to market. Journal of Marketing, 72(July), 90-104.

Fang, E., Palmatier, R., Scher, L., \& Li, N. (2008). Trust at different organizational levels. Journalof Marketing, 72 (March), 80-98.

Fawcett, S. E., Wallin, C., Allred, C., Fawcett, A. M., \& Magnan, G. M. (2011). Information technology as an enabler of supply chain collaboration: A dynamic-capabilities perspective. Journal of Supply Chain Management, 47(1), 38-59.

Fornell, C., \& Larcker, D. F. (1981). Evaluating structural equation models with unobservable variables and measurement error. Journal of Marketing Research, 18(February), 39-50.

Fossas-Olalla, M., Minguela-Rata, B., Lopez-Sanchez, J.-I., \& Fernandez-Menendez, J. (2015). Product innovation: When should suppliers begin to collaborate? Journal of Business Research, 68(7), 1404-1406.

Frohlich, M. T., \& Westbrrok, R. (2001). Arc of integration: An international study of supply chain strategies. Journal of Operations Management, 19(2), 185-200.

Hallen, L., Johanson, J., \& Seyed-Mohamed, N. (1991). Interfirm adaptation in business relationships. Journal of Marketing, 55 (April), 29-37.

Hitt, L. M., \& Brynjolfsson, E. (1996). Productivity, profit, and consumer welfare: Three different measures of information technology value. MIS Quarterly, 20(2), 121-142.

Hitt, M. A., Ireland, R. D., Sirmon, D. G., and Trahms, C. A. (2011). Strategic Entrepreneurship: Creating Value for Individuals, Organizations, and Society. Academy of Management Perspectives, 25(2), 57-75.

Ireland, R. D., Hitt, M. A., and Vaidyanath, D. (2002). Alliance Management as a Source of Competitive Advantage. Journal of Management, 28 (3), 413-446.

Jap, S. D. (1999). Pie-expansion efforts: Collaboration processes in buyer-supplier relationships. Journal of Marketing Research, 36(November), 461-475.

Jaworski, B. J., \& Kohli, A. K. (1993). Market orientation: Antecedents and consequences. Journal of Marketing, 57(July), 53-70.

Jean, R., Sinkovics, R., \& Cavusgil, S. (2010). Enhancing international customer-supplier relationships through IT resources: a study of Taiwanese electronics suppliers. Journal of International Business Studies, 41, 1218-1239.

Jean, R., Sinkovics, R., \& Hiebaum, T. (2014). The effects of supplier involvement and knowledge protection on product innovation in customer-supplier relationships: a study of global automotive suppliers in China. Journal of Product Innovation Management, 31 (1), 98-113.

Jiang, Z., Henneberg, S. C., \& Naudé, P. (2011). The importance of trust vis-à-vis reliance in business relationships: some international findings. International marketing review, 28(4), 318-339.

I, C. (2004). Too much of a good thing? Negative effects of high trust and individual autonomy in selfmanaging teams. Academy of Management Journal, 47 (3), 385-399.

Lee, R. P., Johnson, J. L., and Tang, X. (2012). An investigation into the role of IT integration, relationship predictability and routinization in interfirm relationships: From the structuration perspective. IndustrialMarketing Management, 41, 368-377.

Lee, M. \& Scott, K. (2015). Leveraging IT resources, embeddedness, and dependence: a supplier's perspective on appropriating benefits with powerful buyers. Information \& Management, 52, 909-924.

Lucas, H. (1999). Information technology and the productivity paradox: Assessing the value off investing in it. New York: Orford University Press.

McEvily, B., Perrone, V., \&Zaheer, A. (2003). Trust as an organizing principle. Organization Science, 14 (1), 91-103. 
Menguc, B., Auh, S., \& Yannopoulos, P. (2014). Customer and supplier involvement in design: The moderating role of incremental and radical innovation capability. Journal of Product Innovation Management, 31(2), 313-328.

Morgan, R.M. \& Hunt, S.D. (1994). The commitment-trust theory of relationship marketing. Journalof Marketing 58 (July), 20-38.

Narayanan, S., Narasimhan, R., \& Schoenherr, T. (2015). Assessing the contingent effects of collaboration agility performance in buyer-supplier relationships. Journal of Operations Management, 33-34, 140-154.

Palmatier, R. W., Dant, R. P., Grewal, D., and Evans, K. E. (2006). Factors influencing the Effectiveness of Relationship Marketing: A Meta-Analysis. Journal of Marketing, 70 (October), 136-153.

Perols, J., Zimmermann, C., \& Kortmann, S. (2013). On the relationship between supplier int egration and time-to-market. Journal of Operations Management, 31, 153-167.

Petersen, K., Handfield, R., \& Ragatz, G. (2003). A model of supplier integration into new product development. Journal of Product Innovation Management, 20, 284-299.

Podsakoff, P. M., Mackenzie, S. B., \& Podsakoff, N. P. (2012). Sources of method bias in social science research and recommendations on how to control it. Annual Review of Psychology, 65, 539-569.

Primo, M. A. M., \& Amundson, S. D. (2002). An exploratory study of the effects of supplier relationships on new product development outcomes. Journal of Operations Management, 20(1), 33-52.

Ragatz, G., Handfield, R., \& Scannell, T. (1997). Success factors for integrating suppliers into new product development. Journal of Product Innovation Management, 14, 190-202.

Rodrigues, A.M., Stank, T.P., \& Lynch, D.F. (2004). Linking strategy, structure, process, and performance in integrated logistics. Journal of Business Logistics, 25, 65-94.

Ryssel, R., Ritter, T., \& Gemunden, H. (2004). The impact of information technology deployment on trust, commitment and value creation in business relationships. Journal of Business \& Industrial Marketing, 19 (3), 197-207.

Saeed, K.A., Malhotra, M.K., \& Grover, V. (2011). Interorganizational system characteristics and supply chain integration: an empirical assessment. Decision Science, 42 (1), 7-42.

Santhanam, R., \& Hartono, E. (2003). Issues in linking information technology capability to firm performance. MIS Quarterly, 27(1), 125-153.

Selnes, F. \& Sallis, J. (2003). Promoting relationship learning. Journal of Marketing, 67 (July), 80-95.

Siemsen, E., Roth, A., \& Oliveira, P. (2010). Common method bias in regression models with linear, quadratic, and interaction effects. Organizational Research Methods, 13, 456-476.

Sirmon, D. G. and Hitt, M. A. (2009). Contingencies Within Dynamic Managerial Capabilities: Interdependent Effects of Resource Investment and Deployment on Firm Performance. Strategic Management Journal, 30, 1375-1394.

Sirmon, D. G., Hitt, M. A., Ireland, R. D., and Gilbert, B. A. (2011). Resource Orchestration to Create Competitive Advantage: Breadth, Depth, and Life Cycle Effects. Journal of Management, 37 (5), 1390-1412.

Slater, S. F., \& Narver, J. C. (1994). Does competitive environment moderate the market orientationperformance relationship? Journal of Marketing, 58(1), 46-55.

Smets, L., Oorschot, K., \& Langerak, F. (2013). Don't trust trust: a dynamicapproach to controlling supplier involvement in new product development. Journal of Product Innovation Management, 30 (6), 1145-1158.

Smith, J. \& Barclay, D. (1999). Selling partner relationships: the role of interdependence and relative influence. Journal of Personal Selling \& Sales Management, XIX (4), 21-40.

Song, M., \& Di Benedetto, A. (2008). Supplier's involvement and success of radical new product development in new ventures. Journal of Operations Management, 26(1), 1-22. 
Swink, M., Narasimhan, R., \& Wang, C. (2007). Managing beyond the factory walls: effects of four types of integration on manufacturing plant performance. Journal of Operations Management, 25, 148-164.

To, C. K. M. (2016). Collaboration modes, preconditions, and contingencies in organizational alliance: A comparative assessment. Journal of Business Research, 69(11), 4737-4743.

Vanpoucke, E., Vereecke, A., \& Wetzels, M. (2014). Developing supplier integration capabilities for sustainable competitive advantage: a dynamic capabilities approach. Journal of Operations Management, 32, 446-461.

Vereecke, A. \& Muylle, S. (2006). Performance improvement through supply chain collaboration in Europe. International Journal of Operations and Production Management, 26 (11), 1176-1198.

Villena, V., Revilla, E., \& Choi, T. (2011). The dark side of buyer-supplier relationships: a social capital perspective. Journal of Operations Management, 29, 561-576.

Vorhies, D. W., \& Morgan, N. A. (2005). Benchmarking marketing capabilities for sustainable competitive advantage. Journal of Marketing, 69(1), 80-94.

Walter, A. (2003). Relationship-specificfactors influencing supplier involvement in customer new product development. Journal of Business Research, 56, 721-733.

Wathne, K.H. \& Heide, J.B. (2004). Relationship governance in a supply chain network. Journalof Marketing, 68 (1), 73-89.

Wernerfelt, B. (1984). A resource-based view of the firm. Strategic Management Journal, 5(2), 171-180.

Williams, L. J., Hartman, N., \& Cavazotte, F. (2010). Method Variance and Marker Variables: A Review and Comprehensive CFA Market Technique. Organizational Research Methods, 13(3), 477-514.

Wu, J., Wu, Z., \& Si, S. (2016). The influences of internet-based collaboration and intimate interactions in buyer-supplier relationship on product innovation. Journal of Business Research, 69(9), 37803787.

Yeniyurt, S., Henke, J., \& Yalcinkaya, G. (2014). A longitudinal analysis of supplier involvement in buyer s' new product development: working relations, inter-dependence, co-innovation, and performance outcomes. Journal of the Academy of Marketing Science, 42, 291-308. 